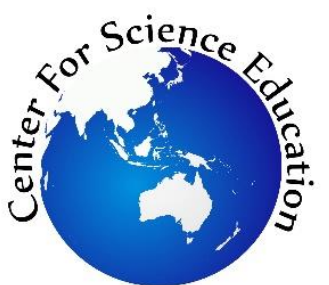

Tersedia online di EDUSAINS

Website: http://journal.uinjkt.ac.id/index.php/edusains

EDUSAINS, 12(2), 2020, 252-258

Research Artikel

EDUS:

\title{
HUBUNGAN ANTARA SELF REGULATED LEARNING DENGAN PROKRASTINASI AKADEMIK PADA MAHASISWA PENDIDIKAN KIMIA DI MASA PANDEMI COVID-19
}

\section{RELATIONSHIP BETWEEN SELF REGULATED LEARNING AND ACADEMIC PROCRASTINATION IN CHEMISTRY EDUCATION STUDENTS IN THE COVID-19 PANDEMIC}

\author{
Arivia Monique Rizkyani*, Tonih Feronika, Nanda Saridewi \\ UIN Syarif Hidayatullah Jakarta, Indonesia \\ *moniquearivia@gmail.com
}

\begin{abstract}
The world, including Indonesia, is being hit by the covid-19 outbreak, making students adapt to a new learning process, namely online. Students need self-regulated learning to direct the learning process to achieve optimal learning goals and suppress the level of academic procrastination experienced by students during the covid-19 pandemic. This study aims to determine the relationship between self-regulated learning and academic procrastination in Chemistry Education students during the covid-19 pandemic. This study uses a correlational method with a quantitative research approach. This study's population was 210 students of Chemistry Education class 2017, 2018, and 2019 with a sample size of 68 students who were determined using the proportional stratified random sampling technique. The instruments used were self-regulated learning questionnaires, academic procrastination questionnaires, and interviews. The product-moment correlation technique is used to test the hypothesis. The results obtained a correlation coefficient value of -0.409 with a significance of 0.001, so it can be said that there is a negative and significant relationship between selfregulated learning and academic procrastination in Chemistry Education students during the covid-19 pandemic.
\end{abstract}

Keywords: covid-19 pandemic, learning process, self-regulated learning, academic procrastination, chemistry education students

\begin{abstract}
Abstrak
Saat ini dunia termasuk Indonesia sedang dilanda wabah covid-19 yang membuat mahasiswa harus beradaptasi dengan proses pembelajaran baru yakni melalui daring. Mahasiswa membutuhkan kemampuan self regulated learning untuk mengarahkan proses belajar dalam mencapai tujuan pembelajaran yang optimal serta untuk menekan tingkat prokrastinasi akademik yang dialami mahasiswa pada masa pandemi covid-19. Penelitian ini. bertujuan untuk. mengetahui. hubungan antara. self regulated.learning dengan. Prokrastinasi. akademik pada mahasiswa. Pendidikan Kimia di.masa pandemi covid-19. Penelitian ini menggunakan metode korelasional dengan pendekatan penelitian kuantitatif. Populasi penelitian ini adalah mahasiswa Pendidikan Kimia angkatan 2017, 2018, dan 2019 berjumlah 210 mahasiswa dengan jumlah sampel sebanyak 68 mahasiswa yang ditentukan menggunakan teknik proportional stratified random sampling. Instrumen yang digunakan berupa angket self regulated learning, angket prokrastinasi akademik, dan wawancara. Teknik korelasi product moment digunakan untuk menguji hipotesis. Hasil penelitian diperoleh nilai .koefisien korelasi sebesar. $-0,409$ dengan. signifikansi 0,001 sehingga.dapat dikatakan bahwa terdapat hubungan.negatif dan signifikan.antara self. regulated. learning dengan prokrastinasi akademik pada. mahasiswa Pendidikan Kimia di.masa pandemi covid-19.
\end{abstract}

Kata Kunci: pandemi covid-19, proses belajar, self regulated learning, prokrastinasi akademik, mahasiswa pendidikan kimia

Permalink/DOI: http:// doi.org/10.15408/es.v12i2.18175 


\section{PENDAHULUAN}

Salah satu sarana utama yang dapat mengoptimalkan. potensi eksistensi dalam diri manusia yaitu sistem pendidikan (Indah \& Shofiah, 2012). Pendidikan menurut Undang-Undang Nomor 20 Tahun 2003 tentang sistem pendidikan nasional pada pasal 1 ayat 1 berbunyi "Pendidikan adalah usaha sadar dan terencana untuk mewujudkan suasana belajar dan proses pembelajaran agar peserta didik secara aktif mengembangkan potensi dirinya untuk memiliki kekuatan spiritual, keagamaan, pengendalian diri, kepribadian, kecerdasan, akhlak mulia, serta keterampilan yang diperlukan dirinya, masyarakat, bangsa, dan negara".

Jannah dan Muis (2014) menyatakan bahwa. dalam. mewujudkan individu yang mandiri, bermartabat,. tangguh, dan kreatif merupakan peran penting yang dilakukan oleh perguruan tinggi yang menjadi salah satu lembaga pendidikan formal. Badan Standar Nasional Pendidikan Tahun 2010 dalam. (Liling, et.al, 2013) menyatakan bahwa. salah satu institusi pendidikan yang ada dan berperan untuk mendukung pencapaian. tujuan. pendidikan nasional adalah.. perguruan tinggi.

Individu yang menempuh ilmu pendidikan dalam suatu perguruan tinggi atau universitas disebut sebagai mahasiswa. Perubahan predikat dari siswa menjadi mahasiswa menunjukkan bahwa individu mengalami peningkatan dalam hal kedewasaan, mulai dari sikap mandiri, pola pikir, tanggung jawab, dan potensi diri. Mahasiswa merupakan suatu tahapan pendidikan formal yang menuntut individu untuk dapat bertindak dan menghasilkan karya (Anggraini, 2016).

Sebagai mahasiswa dalam menempuh ilmu pendidikan terdapat kewajiban yang harus dituntaskan, diantaranya yaitu mengerjakan tugastugas akademik dan menyelesaikan studi yang ditempuh dengan tepat waktu untuk memperoleh gelar sarjana. Namun, tidak dapat dipungkiri bahwa sampai saat ini terdapat persoalan klasik yang masih marak terjadi pada sistem pendidikan Indonesia, salah satunya terjadi pada perguruan tinggi yaitu adanya tindakan prokrastinasi akademik yang seringkali masih dilakukan oleh para mahasiswa.

Mahasiswa Pendidikan Kimia UIN Syarif Hidayatullah Jakarta memiliki aktivitas akademik yang padat. Hal tersebut menjadi salah satu alasan mahasiwa sulit dalam melakukan identifikasi terhadap aktivitas akademiknya, sehingga hal tersebut dapat menjadi penyebab munculnya tindakan prokrastinasi akademik pada mahasiswa Pendidikan Kimia. Prokrastinasi akademik merupakan suatu perilaku menunda-nunda kegiatan akademik termasuk tugas kuliah (Solomon \& Rothblum, 1984). Prokrastinasi akademik dapat terjadi karena perilaku belajar mereka yang tidak sesuai dengan niat yang mereka nyatakan, di mana pada sisi lain mereka juga memiliki niat untuk melakukan penundaan dalam belajar (Ferrari, et.al., 1995, hal. 6).

Terlebih lagi saat ini terdapat pandemi covid19 (Corona Virus Disease 2019) yang sedang melanda seluruh penjuru dunia. Covid-19 pertama kali dideteksi di Kota Wuhan, Cina pada bulan Desember 2019. Virus ini berkembang dengan sangat cepat dan menyebar ke negara-negara lain, termasuk Indonesia. Pandemi covid-19 masuk ke Indonesia sejak bulan Maret 2020. Hingga saat ini tanggal 6 November 2020 terkonfirmasi jumlah individu yang terpapar covid-19 di Indonesia mencapai 425.796 kasus positif (covid19.go.id, 5 November 2020).

Adanya pandemi covid-19 menuntut pemerintah Indonesia mengupayakan berbagai macam cara untuk menekan tingkat penyebaran virus yang berbahaya ini. Seluruh sektor di Indonesia terkena dampak dari munculnya virus covid-19, salah satunya yaitu sektor pendidikan. Kebijakan yang dikeluarkan pemerintah dalam sektor pendidikan adalah melakukan proses belajar mengajar di rumah melalui pembelajaran daring atau online. Hal ini juga termasuk pelaksanaan kegiatan perkuliahan di perguruan tinggi atau universitas (Harahap \& Harahap, 2020). Menurut Bao (2020) tenaga pendidik yang meliputi dosen dan guru merupakan elemen penting dalam pengajaran yang dituntut untuk melakukan migrasi besar-besaran pada suatu kondisi yang sebelumnya 
tidak pernah terjadi, yaitu perubahan pendidikan tatap muka menjadi pendidikan melalui daring.

Selama melakukan proses perkuliahan daring tentunya akan ada faktor-faktor yang menghambat proses belajar, diantaranya yaitu tidak semua wilayah di Indonesia terjangkau oleh layanan internet, sebaran jaringan internet yang lamban sewaktu-waktu, dan kemampuan orang tua dalam memberikan fasilitas pendidikan (Herliandry, et.al., 2020). Kemudian, Hudaifah (2020) juga menambahkan bahwa dalam proses perkuliahan daring intensitas pertemuan antara mahasiswa dan dosen akan berkurang. Hal tersebut dapat menyebabkan kurangnya pengawasan dosen terhadap mahasiswa dalam proses pembelajaran. Dosen akan kesulitan dalam mengawasi proses belajar mahasiswa secara langsung, sehingga mahasiswa akan merasa lebih bebas berada di rumah atau tempat lainnya dan terlepas dari pengawasan dosen.

Meskipun adanya faktor-faktor penghambat dalam aktivitas perkuliahan daring, mahasiswa diharapkan mampu bertanggung jawab atas pembuatan keputusan yang berkaitan dengan proses belajarnya dan mampu memanfaatkan kemampuan self regulated learning yang dimilikinya walaupun dihadapkan pada situasi saat ini. Menurut Zumbrunn (2011, hal. 4) suatu proses yang dapat membantu mahasiswa mengelola pikiran, perilaku, dan emosi yang mereka miliki sehingga mereka mampu mengarahkan pengalaman belajar mereka disebut juga dengan self regulated learning.

Mahasiswa sangat membutuhkan kemampuan self regulated learning dalam proses belajarnya untuk meminimalisir tindakan prokrastinasi akademik yang dialami dirinya. Penelitian Santika dan Sawitri (2016) menemukan bahwa tingginya kemampuan. self regulated learning mampu menekan tingkat prokrastinasi akademik menjadi lebih rendah. Di tengah pandemi covid-19 saat ini mahasiswa harus lebih disiplin pada dirinya sendiri dalam mengelola dan mengarahkan proses belajar mereka agar dapat mencapai tujuan pembelajaran yang mereka inginkan. Sehingga peneliti tertarik meneliti bagaimana hubungan. antara self regulated. learning dengan. prokrastinasi akademik pada. mahasiswa. pendidikan kimia di.masa pandemi covid-19.

\section{METODE}

Penelitian ini menggunakan metode penelitian korelasional dengan pendekatan penelitian secara kuantitatif. Jumlah populasi dalam penelitian ini sebanyak 210 mahasiswa Pendidikan Kimia angkatan 2017, 2018, dan 2019 yang melakukan kegiatan perkuliahan secara daring. Di mana sampel penelitian yang digunakan sebanyak 68 mahasiswa yang ditentukan melalui teknik proportional stratified random sampling. Instrumen penelitian ini berupa angket skala likert dan wawancara. Teknik korelasi Product Moment digunakan sebagai pengujian hipotesis dalam penelitian ini yang bertujuan untuk menentukan adanya hubungan antara. self regulated. learning dan. prokrastinasi akademik.

\section{HASIL DAN PEMBAHASAN}

Berikut ini disajikan ukuran pemusatan data yang terdiri dari mean, median, dan modus pada variabel self. regulated Learning dan. prokrastinasi. akademik melalui Tabel 1.

Tabel 1. Ukuran Pemusatan Data Self Regulated Learning dan Prokrastinasi Akademik

\begin{tabular}{lll}
\hline $\begin{array}{l}\text { Ukuran } \\
\text { Pemusatan Data }\end{array}$ & $\begin{array}{l}\text { Self Regulated } \\
\text { Learning }\end{array}$ & $\begin{array}{l}\text { Prokrastinasi } \\
\text { Akademik }\end{array}$ \\
\hline Mean & 130,35 & 54,34 \\
\hline Median & 128,50 & 53,50 \\
\hline Modus & 119 & 49 \\
\hline
\end{tabular}

Berdasarkan data yang diperoleh diketahui bahwa variabel self. regulated learning dan. prokrastinasi. akademik memiliki ukuran pemusatan data dengan skor yang saling berdekatan. Sehingga dapat dikatakan bahwa data yang terdapat pada kedua variabel berdistribusi normal.

Tinggi rendahnya kemampuan self regulated. learning dan. tingkat prokrastinasi. akademik mahasiswa Pendidikan Kimia dapat dilihat dari hasil penggolongan berdasarkan kategori. 
Penggolongan kategori dari kedua variabel disajikan pada Tabel 2.

Tabel 2. Penggolongan kategori Self Regulated Learning dan Prokrastinasi Akademik

\begin{tabular}{|c|c|c|c|}
\hline \multirow[t]{2}{*}{ Interval Skor } & \multirow[t]{2}{*}{ Kategori } & \multicolumn{2}{|c|}{$\begin{array}{l}\text { Self Regulated } \\
\text { Learning }\end{array}$} \\
\hline & & $\mathbf{F}$ & $\%$ \\
\hline $113,67 \leq X$ & Tinggii & 67. & $98,52 \%$. \\
\hline $72,33 \leq X<113,67$ & Sedangg & 1. & $1,48 \%$ \\
\hline$X<72,33$ & Rendahh & 0. & $0 \%$ \\
\hline Jumlahi & & 68 & $100 \%$ \\
\hline \multirow[t]{2}{*}{ Interval Skor } & Kategori & \multicolumn{2}{|c|}{$\begin{array}{l}\text { Prokrastinasi } \\
\text { Akademik }\end{array}$} \\
\hline & & $\mathbf{F}$ & $\%$ \\
\hline $80,67 \leq X$ & Tinggii & 0 & $0 \%$ \\
\hline $51,33 \leq X<80,67$ & Sedang & 43 & $63,24 \%$ \\
\hline$X<51,33$ & Rendah & 25 & $36,76 \%$ \\
\hline Jumlah & & 68 & $100 \%$ \\
\hline
\end{tabular}

Berdasarkan hasil yang telah disajikan, maka dapat diketahui bahwa kemampuan self regulated learning mahasiswa Pendidikan Kimia berada pada kategori tinggi dengan persentase paling besar yaitu 98,52\%. Sedangkan tingkat prokrastinasi akademik mahasiswa Pendidikan Kimia tergolong ke dalam kategori sedang dengan persentase yang diperoleh sebesar $63,24 \%$.

Tahap selanjutnya adalah pengujian persyaratan analisis yang terdiri dari uji normalitas dan linearitas. Pengujian persyaratan analisis merupakan suatu tahapan penting yang harus dilakukan dalam penelitian ini sebelum melakukan pengujian hipotesis. Hasil dari uji normalitas self. regulated. learning dengan prokrastinasi. akademik disajikan pada tabel 3.

Tabel 3. Uji Normalitas Self Regulated Learning dengan Prokrastinasi Akademik

\begin{tabular}{lll}
\hline Data & $\begin{array}{l}\text { Self Regulated } \\
\text { Learning }\end{array}$ & $\begin{array}{l}\text { Prokrastinasi } \\
\text { Akademik }\end{array}$ \\
\hline$\alpha$. & 0,05 & 0,05 \\
\hline Sig. & 0,094 & 0,200 \\
\hline Kesimpulan & $\begin{array}{l}\text { Sig }>\alpha \\
\text { Data menunjukkan berdistribusi normal }\end{array}$ \\
\hline
\end{tabular}

Berdasarkan analisis data dapat dilihat bahwa uji normalitas pada data self regulated learning memperoleh nilai signifikansi (Sig.) sebesar 0,094 dan data prokrastinasi akademik sebesar 0,200.
Nilai signifikansi (Sig.) yang diperoleh menyatakan bahwa data self regulated learning dan prokrastinasi akademik berdistribusi normal. Hal ini ditunjukkan dengan nilai signifikansi (Sig.) pada kedua variabel $>0,05(\alpha)$.

Uji linearitas pada penelitian ini bertujuan untuk memprediksi apakah hubungan yang terjadi antara self regulated. learning dengan. prokrastinasi akademik berbentuk. garis lurus (linear) atau tidak. Hasil uji linearitas pada tabel 4.

Tabel 4. Uji Linearitas Self Regulated Learning dengan Prokrastinasi Akademik

\begin{tabular}{lll}
\hline Data & $\begin{array}{l}\text { Deviation } \\
\text { Linearity }\end{array}$ & of \\
\cline { 2 - 3 } & $\boldsymbol{\alpha .}$ & Sig. \\
\hline $\begin{array}{l}\text { Self Regulated Learning dengan } \\
\text { Prokrasinasi Akademik }\end{array}$ & 0,05 & 0,547 \\
& & \\
\hline
\end{tabular}

Analisis data yang diperoleh menunjukkan bahwa nilai signifikansi (Sig.) pada uji linearitas self regulated learning dengan prokrastinasi akademik sebesar 0,547. Artinya, nilai signifikansi (Sig.) > 0,05 maka dapat dinyatakan bahwa hubungan yang terjadi linear antara self. regulated. learning dengan prokrastinasi. akademik berbentuk garis lurus atau linear.

Pengujian hipotesis yang dilakukan menggunakan teknik korelasi Product Moment dengan bantuan program SPSS versi 25 memperoleh hasil analisis data pada tabel 5 .

Tabel 5. Hasil Uji Korelasi Product Moment

\section{Correlations}

Self Prokrastinasi

Regulated Akademik

Learning

\begin{tabular}{|c|c|c|c|}
\hline \multirow{3}{*}{$\begin{array}{l}\text { Self } \\
\text { Regulated } \\
\text { Learning }\end{array}$} & $\begin{array}{l}\text { Pearson } \\
\text { Correlation }\end{array}$ & 1 & $-.409^{*}$ \\
\hline & $\begin{array}{l}\text { Sig. } \\
\text { tailed) }\end{array}$ & & .001 \\
\hline & $\mathrm{N}$ & 68 & 68 \\
\hline \multirow[t]{3}{*}{$\begin{array}{l}\text { Prokrastinasi } \\
\text { Akademik }\end{array}$} & $\begin{array}{l}\text { Pearson } \\
\text { Correlation }\end{array}$ & $-.409^{* * *}$ & 1 \\
\hline & $\begin{array}{l}\text { Sig. } \\
\text { tailed) }\end{array}$ & .001 & \\
\hline & $\mathrm{N}$ & 1 & $-.409^{* *}$ \\
\hline
\end{tabular}

Hasil uji korelasi pada penelitian ini menunjukkan bahwa nilai koefisien korelasi $\left(\mathrm{r}_{\mathrm{xy}}\right)$ yang diperoleh antara self regulated. learning 
dengan. prokrastinasi akademik. sebesar. - 0,409 dengan signifikansi. (Sig.) sebesar 0,001. Tanda negatif pada nilai koefisien korelasi menandakan bahwa hubungan yang terjadi antara self regulated learning dengan prokrastinasi akademik saling berlawanan. Hubungan yang berlawanan menunjukkan bahwa apabila terjadinya kenaikan pada salah satu variabel, maka variabel lainnya akan mengalami penurunan (Rizanti, 2013). Nilai signifikansi yang diperoleh pada penelitian ini < 0,05 sehingga dapat diketahui bahwa antara variabel self regulated. lerning dengan. prokrastinasi akademik memiliki. hubungan. yang signifikan.

Berdasarkan hasil penelitian maka hipotesis $\left(\mathrm{H}_{1}\right)$ yang berbunyi "Terdapat hubungan yang signifikan. negatif antara self regulated. learning dengan prokrastinasi akademik pada. mahasiswa Pendidikan. Kimia UIN Syarif Hidayatullah Jakarta di masa pandemi covid-19" diterima. Pengujian hipotesis dinyatakan diterima karena hasil uji korelasi menunjukkan adanya hubungan yang. negatif dan. signifikan antara variabel. self regulated learning dengan prokrastinasi. akademik pada mahasiswa Pendidikan Kimia.

Nilai koefisien. korelasi yang. bertanda negatif menunjukkan bahwa. semakin tinggi kemampuan self. regulated. learning yang dimiliki. mahasiswa maka akan semakin rendah tingkat. prokrastinasi akademiknya, dan begitupun. sebaliknya. Hal ini diperkuat dengan penelitian Rohmaniyah (2018) yang menyatakan bahwa koefisien korelasi negatif menandakan semakin tinggi self regulated learning, maka prokrastinasi akademik akan semakin rendah.

Penelitian ini memperoleh koefisien korelasi $\left(\mathrm{r}_{\mathrm{xy}}\right)$ sebesar $-0,409$ yang berarti nilai korelasi tersebut terletak pada interval 0,40 - 0,599, sehingga dapat dikatakan bahwa hubungan yang. terjadi antara. self regulated learning dengan. prokrastinasi akademik pada. mahasiswa Pendidikan Kimia di. masa pandemi covid-19 termasuk ke dalam kategori sedang. Sesuai dengan penelitian Kurniawan (2013) yang memperoleh nilai koefisien korelasi $\left(\mathrm{r}_{\mathrm{xy}}\right)=-0,652$ dan signifikansi (Sig.) $=0,000$, artinya terdapat hubungan yang berbanding terbalik, di mana hubungan yang terjadi ialah hubungan yang negatif dan tergolong sedang.

Hasil temuan secara keseluruhan pada penelitian ini menunjukkan meskipun kemampuan self. regulated. learning yang dimiliki. mahasiswa Pendidikan kimia tergolong. tinggi, namun mereka juga masih melakukan tindakan prokrastinasi dalam aktivitas akademiknya. Adanya pandemi covid-19 menuntut mahasiswa untuk melakukan aktivitas perkuliahan melalui daring atau online. Salah satu indikator dominan yang dapat menyebabkan munculnya prokrastinasi akademik pada mahasiswa Pendidikan Kimia adalah gangguan perhatian.

Berdasarkan hasil wawancara yang dilakukan dengan salah satu mahasiswa Pendidikan Kimia angkatan 2019 ditemukan bahwa hal yang paling mengganggu dalam aktivitas akademiknya selama perkuliahan daring adalah banyaknya notifikasi dari sosial media pada hp atau laptop ketika sedang berlangsungnya perkuliahan melalui daring. Hal ini menandakan bahwa gangguan perhatian memiliki kontribusi yang besar dalam mempengaruhi tindakan prokrastinasi akademik mahasiswa Pendidikan Kimia di masa pandemi covid-19. Sesuai dengan Steel (2007) yang menyatakan bahwa salah satu alasan utama mahasiswa melakukan prokrastinasi akademik karena adanya gangguan perhatian. Muyana (2018) juga menegaskan bahwa mahasiswa memerlukan konsentrasi yang penuh ketika dihadapkan dengan pemusatan akan perhatian terhadap suatu objek.

Sistem perkuliahan tatap muka yang berubah menjadi perkuliahan daring di masa pandemi covid19, tentunya memberikan banyak perubahan terhadap pola dan proses belajar mahasiswa Pendidikan Kimia. Maka dari itu, mahasiswa perlu menyesuaikan kemampuan self regulated learning yang dimilikinya dalam melakukan proses pembelajaran daring pada masa pandemi covid-19 saat ini. Hal tersebut perlu diterapkan agar mahasiswa mampu mengelola proses belajar mereka serta dapat menahan tingkat prokrastinasi akademik yang dialami mahasiswa dalam melakukan aktivitas akademik pada masa pandemi covid-19. Herliandry, et al (2020) menyatakan bahwa menciptakan kemandirian dan keterampilan 
belajar mahasiswa di tengah pandemi covid-19 merupakan hal yang paling penting.

\section{PENUTUP}

Berdasarkan hasil. penelitian maka dapat. ditarik kesimpulan. bahwa terdapat hubungan yang. signifikan. negatif antara self regulated learning dengan prokrastinasi. akademik pada. mahasiswa Pendidikan Kimia UIN. Syarif Hidayatullah Jakarta di masa. pandemi covid-19. Koefisien korelasi menunjukkan nilai $r$ sebesar - 0,409 sehingga dapat dinyatakan bahwa hubungan kedua variabel tergolong dalam korelasi sedang.

Peneliti mengharapkan adanya penelitian lanjutan serupa yang membahas dan mengembangkan hal-hal yang lebih mendetail terkait tindakan prokrastinasi akademik yang belum diungkapkan dalam penelitian ini. Selain itu peneliti juga memberikan saran kepada peneliti berikutnya untuk mengulik variabel-variabel lain yang diduga juga memiliki hubungan dengan variabel prokrastinasi akademik.

\section{UCAPAN TERIMA KASIH}

Ucapan terima kasih diberikan kepada mahasiswa Pendidikan Kimia angkatan 2017, 2018, dan 2019 yang telah bersedia menjadi responden dalam penelitian ini. Serta terima kasih kepada dosen Program Studi Pendidikan Kimia UIN Syarif Hidayatullah Jakarta yang telah memberikan dukungan selama penelitian.

\section{DAFTAR PUSTAKA}

Anggraini, W. N. (2016). Hubungan antara Daya Juang dengan Prokrastinasi Akademik pada Mahasiswa Tingkat Akhir yang Mengerjakan Skripsi. 1-8.

Bao, W. (2020). COVID - 19 and Online teaching in Higher Education: A case study of Peking University. Human Behavior and Emerging Technologies, 2(2), 113-115.

Ferrari, J. R., Johnson, J. L., McCown, W. G. (1995). Procrastination and Task Avoidance: Theory, Research, and Treatment.
Harahap, A. C. P., \& Harahap, S. R. (2020). Covid 19: Self Regulated Learning Mahasiswa. Jurnal pendidikan dan konseling, 10(1), 3642.

Herliandry, L. D., Nurhasanah, N., Suban, M. E., \& Kuswanto, H. (2020). Pembelajaran Pada Masa Pandemi Covid-19. JTP - Jurnal Teknologi Pendidikan, 22(1), 65-70.

Hudaifah, F. (2020). Peran Self Regulated Learning di Era Pandemi Covid-19. Biormatika: Jurnal Ilmiah Fakultas Keguruan dan Ilmu Pendidikan, 6(2), 76-84.

Indah, P. S., \& Shofiah, V. (2012). Hubungan Prokrastinasi Akademik dengan Ketidakjujuran Akademik pada Mahasiswa Psikologi UIN Suska Riau. Jurnal Psikologi UIN Sultan Syarif Kasim Riau, 8(1), 29-36.

Jannah, M., \& Muis, D. T. (2014). Prokrastinasi Akademik (Perilaku Penundaan Akademik) Mahasiswa Fakultas Ilmu Pendidikan Universitas Negeri Surabaya. Jurnal Bimbingan Konseling Unesa, 4(3), 1-8.

Kurniawan, R. (2013). Hubungan antara Self Regulated Learning dengan Prokrastinasi Akademik pada Mahasiswa Jurusan Psikologi.

Muyana, S. (2018). Prokrastinasi akademik di Kalangan Mahasiswa Program Studi Bimbingan dan Konseling. Counsellia: Jurnal Bimbingan dan Konseling, 8(1), 4552.

Rizanti, F. D. (2013). Hubungan antara Self Regulated Learning dengan Prokrastinasi Akademik dalam Menghafal Alquran pada Mahasantri Ma'Had 'Aly Masjid Nasional Al-Akbar. Jurnal Penelitian Psikologi., 02(01), 1-7.

Rohmaniyah, A. (2018). Hubungan antara Self Regulated Learning dengan Prokrastinasi Akademik pada Anggota BEM Universitas X. Character: Jurnal Penelitian Psikologi., $5(2), 1-6$. 
Rizkyani, A. M., Feronika, T., Saridewi, N.

Santika, W. S., \& Sawitri, D. R. (2016). SelfRegulated Learning dan Prokrastinasi Akademik pada Siswa Kelas XI SMA Negeri 2 Purwokerto. Empati, 5(1), 44-49.

Solomon, L. J., \& Rothblum, E. D. (1984). Academic Procrastination: Frequency and Cognitive-Behavioral Correlates. Journal of Counseling Psychology, 31(4), 503-509.
Steel, P. (2007). The Nature of Procrastination: A Meta-Analytic and Theoretical Review of Quintessential Self-Regulatory Failure. Psychological Bulletin, 133(1), 65-94.

Zumbrunn, S. (2011). Encourage Self Regulated Learning in The Classroom. journal Virginia Commonwealth University, 278-299. 